\title{
Oral Health of Parkinson's Disease Patients: A Case-Control Study
}

\author{
Marjolein A. E. van Stiphout $\mathbb{D}^{1}{ }^{1}$ Johan Marinus, ${ }^{2}$ Jacobus J. van Hilten, ${ }^{2}$ \\ Frank Lobbezoo $\mathbb{D D}^{3}$ and Cees de Baat $\mathbb{D}^{1,4}$ \\ ${ }^{1}$ Foundation for Oral Health and Parkinson's Disease, P.O. Box 1155, 2340 BD Oegstgeest, Netherlands \\ ${ }^{2}$ Department of Neurology, Leiden University Medical Center, Albinusdreef 2, 2333 ZA Leiden, Netherlands \\ ${ }^{3}$ Department of Oral Kinesiology, Academic Centre for Dentistry Amsterdam (ACTA), \\ University of Amsterdam and Vrije Universiteit Amsterdam, Gustav Mahlerlaan 3004, 1081 LA Amsterdam, Netherlands \\ ${ }^{4}$ Department of Dentistry, Radboud university medical center, P.O. Box 9101, 6500 HB Nijmegen, Netherlands
}

Correspondence should be addressed to Cees de Baat; debaat_cees@hotmail.com

Received 21 January 2018; Accepted 1 April 2018; Published 8 May 2018

Academic Editor: Hélio Teive

Copyright (c) 2018 Marjolein A. E. van Stiphout et al. This is an open access article distributed under the Creative Commons Attribution License, which permits unrestricted use, distribution, and reproduction in any medium, provided the original work is properly cited.

\begin{abstract}
The aim of the study was to examine the oral health status of Parkinson's disease (PD) patients, to compare their oral health status to that of a control group, and to relate it to the duration and severity of PD. Materials and Methods. 74 PD patients and 74 controls were interviewed and orally examined. Among PD patients, the duration and the Hoehn and Yahr stage (HY) of the disease were registered. Results. More PD patients than controls reported oral hygiene care support as well as chewing/biting problems, taste disturbance, tooth mobility, and xerostomia, whereas dentate patients had more teeth with carious lesions, tooth root remnants, and biofilm. Both longer duration and higher HY were associated with more chewing problems and, in dentates, more teeth with restorations. In dentates, longer duration of the disease was associated with higher number of mobile teeth. Higher HY was associated with more oral hygiene care support as well as biting problems and, in dentates, more teeth with carious lesions and tooth root remnants. Conclusions. Comparatively, PD patients had weakened oral health status and reduced oral hygiene care. Both duration and severity of the disease were associated with more oral health and hygiene care problems.
\end{abstract}

\section{Introduction}

Parkinson's disease is a progressive degenerative neurological disorder, characterized by motor and nonmotor symptoms. The motor symptoms include akinesia, bradykinesia, rigidity, and tremor, which remain not restricted to the trunk and extremities, but may also occur in the orofacial system [1-3]. Motor impairments of the orofacial system include dysphagia, masticatory dysfunction, orofacial dyskinesia, and oromandibular dystonia [4-7]. In addition, related to oral health, the potentially impaired dexterity of arms and fingers may hamper the required daily oral hygiene care [8].

Advances in oral health care and treatment during the past few decades have resulted in a reduced number of edentulous individuals. The proportion of adults who retain their teeth until late in life has increased substantially [9]. Consequently, a still increasing number of dentate older people experience oral health problems, such as dental caries, periodontal disease, and substantial wear of hard tooth tissues (tooth wear). Furthermore, many older people have been treated with oral implants and/or sophisticated tooth- and/or implant-supported fixed and/or removable dental prostheses. Hence, these older people are in continuous need of both preventive and curative oral health care. The complexity of oral health status, the potential presence of systemic diseases, and the use of several medications make older people more vulnerable to oral problems when compared to younger age groups, particularly in those who are cognitively impaired $[10,11]$. In addition, weakened oral health due to neglected oral hygiene care and reduced oral health care utilization has previously been found in older people [11-14].

Oral diseases, such as dental caries and periodontal disease, not only have oral effects, for example oral pain and oral functioning problems, but may also impact a number of systemic conditions. Emerging evidence suggests that poor oral health influences the initiation and/or progression of 
diseases, such as atherosclerosis, diabetes mellitus, Alzheimer's disease, and rheumatoid arthritis [15]. Aspiration of oropharyngeal bacteria may cause pneumonia [15-17]. Concerns were expressed about relationships between older people's poor oral health status and nutrition [18].

Study of the international literature revealed that, when compared to control subjects, Parkinson's disease patients generally had a lower number of teeth, more dental carious lesions, poorer periodontal health, higher objective periodontal treatment needs, more subjective chewing difficulties, more subjective swallowing difficulties, more subjective denture discomfort, more limited active mouth opening, and more negative impact of oral health on daily life (Table 1) [19-28]. However, each of the aforementioned studies investigated only few aspects of oral health; none investigated the whole picture of the oral health status. Furthermore, the relationships between aspects of oral health and the duration and severity of Parkinson's disease have not been addressed.

Therefore, the aim of the current study was to examine the most relevant aspects of the subjective and objective oral health status of Parkinson's disease patients, to compare their oral health status to that of an optimally gender-, age-, social background-, and lifestyle-matched control group, and to relate their oral health status to the duration and severity of Parkinson's disease.

\section{Materials and Methods}

2.1. Study Population. The current cross-sectional, casecontrol, optimally gender-, age-, social background-, and lifestyle-matched study was approved by the Medical Ethical Committee of Leiden University Medical Center, Leiden, the Netherlands, approval number P13.079. Assuming a power (1- $\beta$ ) of 0.80 and an $\alpha$ of 0.05 and an objective to detect a prevalence difference of $25 \%$ between groups across a range of different hypothetical prevalence rates, a sample size calculation indicated that 69 persons per group of Parkinson's disease patients and control subjects would be sufficient.

Patients with Parkinson's disease, without severe comorbidity according to classes III and IV of the Physical Status Classification System of the American Society of Anesthesiologists, were requested to participate when they visited the Department of Neurology of the Leiden University Medical Center, Leiden, the Netherlands, for a routine periodic consultation. The Parkinson's disease patients who agreed to participate, were subsequently requested to identify a control person, for instance a family member or other close relative, who had no Parkinson's disease or other severe systemic diseases according to classes III and IV of the Physical Status Classification System of the American Society of Anesthesiologists, who had approximately the same age ( \pm 5 years) as well as a similar social background and lifestyle, and who would likely be prepared to participate. The group of control subjects was also optimally gender matched, meaning that men with Parkinson's disease preferably indicated men and women with Parkinson's disease preferably indicated women. Assuming that not every person proposed by a Parkinson's disease patient as control subject would agree to participate, initially 74
Parkinson's disease patients were included. All Parkinson's disease patients and indicated control subjects were visited at their homes to inform them about the research project. Luckily, all of them provided informed consent and were subsequently interviewed and examined.

After the interview and the examination, every participant received information on his/her actual oral health condition and was recommended consultation with a dentist in case the actual oral health condition required attention and/or treatment.

2.2. Assessments. Using a common history form, data were gathered about educational level (primary, secondary, and tertiary), smoking habits, length of time since the last oral health consultation, number of oral health consultations during the previous five years, daily oral hygiene care (whether or not supported by a professional or voluntary care provider), type of toothbrush used, chewing problems, biting problems, taste disturbance, burning mouth, xerostomia, halitosis, remaining food particles, tooth mobility, toothache, tooth sensitivity, painful gums, and bleeding gums. Persons with an edentulous maxilla/mandible were requested to indicate the duration since the last teeth in the maxilla/mandible had been removed, the number of years during which a current complete maxillary/mandibular removable dental prosthesis was functioning, and their potential experience with a loose coming complete maxillary/mandibular removable dental prosthesis during oral movements.

An experienced dentist performed an oral health examination in all participants, using a common oral screening form. Variables included were edentulousness, soft tissue lesions, complete or partial maxillary/mandibular removable dental prostheses, number of teeth, number of teeth with carious lesions, number of teeth with restorations, number of tooth root remnants, amount of biofilm and food, periodontal health, and number of posterior functional tooth units, including (implant-supported) single- and multiunit fixed dental prostheses.

The amount of biofilm and food on teeth and soft tissues was assessed by a simple 3-points scale: $1=$ hardly any biofilm and food; 2 = thin layer of biofilm and food; $3=$ thick layer of biofilm and food.

Periodontal health was assessed using the tooth mobility scoring system. This clinically easy-to-determine system differentiates three grades: grade I: mobility in a horizontal direction more than $0.2 \mathrm{~mm}$ and less than $1 \mathrm{~mm}$; grade II: mobility in a horizontal direction of $1 \mathrm{~mm}$ or more; and grade III: mobility in vertical direction [29].

The number of posterior functional tooth units is an important proxy for masticatory efficiency. One maxillary and one mandibular premolar in occluding contact constitute one posterior functional tooth unit. One occluding maxillary and mandibular molar are equivalent to two posterior functional tooth units [30].

In persons with an edentulous maxilla/mandible, the reduction of the edentulous residual alveolar ridge was clinically classified as moderate reduction, high degree of reduction, or extensive reduction, using a standard set of edentulous alveolar ridge models [31]. 
Table 1: Studies on Parkinson's disease and oral health, available in the international literature.

\begin{tabular}{|c|c|c|c|c|c|c|c|}
\hline Publication & Country & Research design & Population & $\begin{array}{l}\text { Results of PD patients when } \\
\text { compared to controls }\end{array}$ & OR & $95 \% \mathrm{CI}$ & $P$ \\
\hline $\begin{array}{l}\text { Nakayama et al., } \\
2004 \text { [19] }\end{array}$ & Japan & $\begin{array}{l}\text { Questionnaire } \\
\text { survey by mail }\end{array}$ & $\begin{array}{l}104 \text { with PD } \\
191 \text { controls }\end{array}$ & $\begin{array}{l}\text { Gender- and age-adjusted: } \\
\text { More chewing difficulties } \\
\text { More denture discomfort } \\
\text { More edentulousness } \\
\text { Less daily denture care } \\
\text { 50\% swallowing problems }\end{array}$ & $\begin{array}{c}6.0 \\
3.9 \\
3.5 \\
10.5\end{array}$ & $\begin{array}{c}2.8-12.8 \\
1.9-8.0 \\
1.8-6.8 \\
2.9-37.3\end{array}$ & \\
\hline $\begin{array}{l}\text { Schwarz et al., } \\
2006[20]\end{array}$ & Germany & $\begin{array}{l}\text { Case-control, } \\
\text { age-matched }\end{array}$ & $\begin{array}{l}70 \text { with } \mathrm{PD} \\
85 \text { controls }\end{array}$ & $\begin{array}{l}\text { Higher scores on indices of the } \\
\text { Community Periodontal Index for } \\
\text { Treatment Needs (CPITN) }\end{array}$ & & & $<0.05$ \\
\hline $\begin{array}{l}\text { Einarsdóttir et al., } \\
2009[21]\end{array}$ & Iceland & Case-control & $\begin{array}{l}67 \text { with PD } \\
55 \text { controls }\end{array}$ & $\begin{array}{c}\text { Lower number of teeth } \\
\text { More dental carious lesions } \\
\text { More biofilm } \\
\text { Poorer periodontal health } \\
\text { Greater number of cariogenic } \\
\text { bacteria in saliva }\end{array}$ & $\begin{array}{l}3.13 \\
2.28\end{array}$ & $\begin{array}{l}1.4-6.9 \\
1.0-4.9\end{array}$ & $\begin{array}{c}<0.036 \\
<0.007 \\
<0.004 \\
0.035 \\
<0.05\end{array}$ \\
\hline $\begin{array}{l}\text { Hanaoka and } \\
\text { Kashihara, } \\
2009[22]\end{array}$ & Japan & $\begin{array}{l}\text { Case-control, } \\
\text { age-matched }\end{array}$ & $\begin{array}{l}89 \text { with PD } \\
68 \text { mild cognitively } \\
\text { impaired } \\
60 \text { with ischemic } \\
\text { stroke } \\
\end{array}$ & $\begin{array}{c}\text { Lower number of teeth } \\
\text { More dental carious lesions } \\
\text { More deep periodontal } \\
\text { pockets }\end{array}$ & & & $\begin{array}{l}<0.05 \\
<0.001 \\
<0.001\end{array}$ \\
\hline $\begin{array}{l}\text { Bakke et al., } \\
2011 \text { [23] }\end{array}$ & Denmark & $\begin{array}{l}\text { Case-control, } \\
\text { age-matched, } \\
\text { gender-matched }\end{array}$ & $\begin{array}{l}15 \text { with moderate } \\
\text { to advanced } \mathrm{PD} \\
15 \text { controls }\end{array}$ & $\begin{array}{c}\text { Overall objective orofacial function } \\
\text { Poorer subjective masticatory } \\
\text { ability } \\
\text { Poorer active mouth opening } \\
\text { More negative impact of oral } \\
\text { health on daily life }\end{array}$ & & & $\begin{array}{l}<0.001 \\
<0.001 \\
<0.001 \\
<0.001\end{array}$ \\
\hline $\begin{array}{l}\text { Müller et al., } \\
2011[24]\end{array}$ & Germany & Case-control & $\begin{array}{l}101 \text { with PD } \\
75 \text { controls }\end{array}$ & $\begin{array}{c}\text { Lower gingival index } \\
\text { Lower frequency of daily tooth } \\
\text { brushing } \\
\text { More dental carious lesions } \\
\text { Longer time since last dental visit } \\
\text { Lower salivary flow rate } \\
\text { More gingival recession } \\
\text { More tooth mobility }\end{array}$ & & & $\begin{array}{l}<0.001 \\
<0.01 \\
<0.01 \\
<0.001 \\
<0.001 \\
<0.001 \\
<0.001\end{array}$ \\
\hline $\begin{array}{l}\text { Cicciù et al., } \\
2012[25]\end{array}$ & Italy & $\begin{array}{l}\text { Case-control, } \\
\text { age-matched }\end{array}$ & $\begin{array}{l}45 \text { with mild to } \\
\text { moderate PD } \\
45 \text { controls }\end{array}$ & $\begin{array}{l}\text { More dental carious lesions } \\
\text { Higher gingival index } \\
\text { Higher sulcus bleeding index } \\
\text { Higher biofilm index }\end{array}$ & & & $\begin{array}{l}\text { not reported } \\
\text { not reported } \\
\text { not reported } \\
\text { not reported }\end{array}$ \\
\hline $\begin{array}{l}\text { Pradeep et al., } \\
2015 \text { [26] }\end{array}$ & India & $\begin{array}{l}\text { Case-control, } \\
\text { age-matched }\end{array}$ & $\begin{array}{l}45 \text { with } \mathrm{PD} \\
46 \text { controls }\end{array}$ & $\begin{array}{l}\text { More periodontal pockets } \\
\text { More periodontal attachment loss } \\
\text { Lower gingival index } \\
\text { Lower biofilm index }\end{array}$ & & & $\begin{array}{l}<0.001 \\
<0.001 \\
<0.001 \\
<0.001\end{array}$ \\
\hline $\begin{array}{l}\text { Ribeiro et al., } \\
2016 \text { [27] }\end{array}$ & Brasil & Case-control & $\begin{array}{l}\text { Wearers of complete } \\
\text { removable dental } \\
\text { prostheses } 17 \text { with PD } \\
20 \text { controls }\end{array}$ & $\begin{array}{l}\text { Poorer self-perception of oral } \\
\text { health }\end{array}$ & & & $<0.04$ \\
\hline $\begin{array}{l}\text { Barbe et al., } \\
2017 \text { [28] }\end{array}$ & Germany & $\begin{array}{l}\text { Questionnaire } \\
\text { survey }\end{array}$ & $\begin{array}{l}100 \text { with PD } \\
\text { Frequencies compared } \\
\text { with results of other } \\
\text { studies }\end{array}$ & $\begin{array}{c}\text { Poorer oral health impact profile, } \\
\text { among others due to complaints } \\
\text { of xerostomia, drooling and } \\
\text { dysphagia }\end{array}$ & & & \\
\hline
\end{tabular}

For Parkinson's disease patients, the duration of the disease (since the onset of motor symptoms) and the severity of the disease expressed by the Hoehn and Yahr stage were registered from the patients' medical records [32]. The duration of the disease was categorized as less than 5 years, between 5 and 9 years, and 10 years or longer.
2.3. Statistical Analysis. Data were analyzed using SPSS version 22.0 (SPSS, Inc., Chicago, IL). Numbers and percentages were compared between groups using a Chi-square test $\left(\chi^{2}\right)$. An independent-samples Student's $t$-test was only used to compare the age of Parkinson's disease patients and control subjects. Mann-Whitney $U$ test was used to compare 
TABLE 2: Frequencies, including percentages, of the general subjective aspects of oral health and the often/occasional oral health complaints of the (dentate) Parkinson's disease patients (PD) and the (dentate) control subjects (control) and the results of the Chi-square test carried out to assess statistically significant differences $(*)$ between PD and control.

\begin{tabular}{|c|c|c|c|}
\hline Variables & $\mathrm{PD}$ & Control & Chi-square test \\
\hline All persons: general subjective variables & $n=74$ & $n=74$ & \\
\hline \multicolumn{4}{|l|}{ Educational level } \\
\hline (i) primary & $18(24 \%)$ & $12(16 \%)$ & \\
\hline (ii) secondary & $21(29 \%)$ & $35(47 \%)$ & \\
\hline (iii) tertiary & $34(46 \%)$ & $27(37 \%)$ & \\
\hline (iv) missing value & $1(1 \%)$ & - & $\chi_{(7)}^{2}=11.947 ; P=0.102$ \\
\hline Smoking status & $6(8.1 \%)$ & $6(8.1 \%)$ & - \\
\hline \multicolumn{4}{|l|}{ Length of time since the last oral health consultation } \\
\hline (i) less than half a year & $52(70.3 \%)$ & $49(66.2 \%)$ & \\
\hline (ii) between a half and two years & $15(20.3 \%)$ & $22(29.8 \%)$ & $\chi_{(5)}^{2}=5.704 ; P=0.336$ \\
\hline \multicolumn{4}{|l|}{ Number of oral health consultations during the previous five years } \\
\hline (i) 0 & $4(5.4 \%)$ & $2(2.7 \%)$ & \\
\hline (ii) $1-5$ & $13(17.6 \%)$ & $17(23.0 \%)$ & \\
\hline (iii) $6-10$ & $30(40.5 \%)$ & $36(48.6 \%)$ & \\
\hline (iv) 11 or more & $27(36.5 \%)$ & $19(25.7 \%)$ & $\chi_{(6)}^{2}=6.607 ; P=0.359$ \\
\hline $\begin{array}{l}\text { Daily oral hygiene care supported by a professional or voluntary } \\
\text { care provider }\end{array}$ & $11(14.9 \%)$ & $1(1.4 \%)$ & $\chi_{(1)}^{2}=9.069 ; P=0.003^{*}$ \\
\hline Electric toothbrush used & $36(48.6 \%)$ & $30(40.5 \%)$ & $\chi_{(3)}^{2}=3.091 ; P=0.378$ \\
\hline All persons: oral health complaints & $n=74$ & $n=74$ & \\
\hline Chewing problems & $22(29.7 \%)$ & $3(4.1 \%)$ & $\chi_{(4)}^{2}=18.973 ; P=0.001^{*}$ \\
\hline Biting problems & $26(35.1 \%)$ & $7(9.5 \%)$ & $\chi_{(4)}^{2}=15.047 ; P=0.005^{*}$ \\
\hline Taste disturbance & $17(23.0 \%)$ & $1(1.4 \%)$ & $\chi_{(4)}^{2}=19.523 ; P=0.001^{*}$ \\
\hline Burning mouth & $3(4.1 \%)$ & 0 & $\chi_{(4)}^{2}=8.0290 ; P=0.091$ \\
\hline Xerostomia & $48(64.9 \%)$ & $24(32.4 \%)$ & $\chi_{(4)}^{2}=19.510 ; P=0.001^{*}$ \\
\hline Halitosis & $14(18.9 \%)$ & $9(12.2 \%)$ & $\chi_{(4)}^{2}=7.037 ; P=0.134$ \\
\hline Remaining food particles & $52(70.3 \%)$ & $51(68.9 \%)$ & $\chi_{(4)}^{2}=2.877 ; P=0.579$ \\
\hline Dentate persons: oral health complaints & $n=65$ & $n=65$ & \\
\hline Tooth mobility & $12(18.5 \%)$ & $2(3.1 \%)$ & $\chi_{(3)}^{2}=11.215 ; P=0.011^{*}$ \\
\hline Toothache & $10(15.4 \%)$ & $6(9.2 \%)$ & $\chi_{(3)}^{2}=2.000 ; P=0.572$ \\
\hline Tooth sensitivity & $17(26.2 \%)$ & $11(16.9 \%)$ & $\chi_{(4)}^{2}=4.500 ; P=0.343$ \\
\hline Painful gums & $12(18.5 \%)$ & $7(10.8 \%)$ & $\chi_{(4)}^{2}=2.810 ; P=0.590$ \\
\hline Bleeding gums & $13(20.0 \%)$ & $12(18.5 \%)$ & $\chi_{(4)}^{2}=5.826 ; P=0.213$ \\
\hline
\end{tabular}

ordinal or nonnormally distributed continuous variables between groups. Kruskal-Wallis test was used to examine group differences of nonnormally distributed continuous variables with three or more categories. Statistical significance was accepted at $P<0.05$. Given the exploratory character of the study, no attempt was made to control for multiple comparisons.

\section{Results}

3.1. Participants. Interviews and oral health examinations were performed in 26 women and 48 men with Parkinson's disease and in 35 female and 39 male control subjects $\left(\chi_{(1)}^{2}=2.259, P=0.133\right)$. Mean age \pm standard deviation was $70.2 \pm 8.8$ years in the Parkinson's disease patients and $67.9 \pm 10.1$ years in the control subjects (Student's $t$-test; $P=0.641)$.

3.2. Subjective Variables. Table 2 presents frequencies and percentages of the subjective variables of the Parkinson's disease patients and the control subjects. When compared to the control subjects, statistically significantly more Parkinson's disease patients reported daily oral hygiene care support by a professional or voluntary care provider, chewing problems, biting problems, taste disturbance, and xerostomia. When compared to the dentate control subjects, statistically significantly more dentate Parkinson's disease patients reported tooth mobility.

The Parkinson's disease patients and control subjects with an edentulous maxilla (and mandible) showed no statistically significant group differences with regard to length of time since the last teeth had been removed, number of years during which a current complete maxillary/ mandibular removable dental prosthesis was functioning, and persons' experiences with a loose coming complete maxillary/mandibular removable dental prosthesis during oral movements.

3.3. Objective Variables. Table 3 presents frequencies and percentages of the objective variables of the Parkinson's disease patients and the control subjects. Statistical analysis of the data of dentate persons did point out that the 
TABLE 3: Frequencies, including percentages, of the objective oral health variables of the Parkinson's disease patients (PD) and the control subjects (control) and statistically significant group differences.

\begin{tabular}{|c|c|c|c|}
\hline Variables & $\mathrm{PD}$ & Control & Statistical test \\
\hline All persons & $n=74$ & $n=74$ & \\
\hline Number of persons with an edentulous maxilla & $14(18.9 \%)$ & $14(18.9 \%)$ & \\
\hline Number of persons with an edentulous maxilla and mandible & $9(12.2 \%)$ & $9(12.2 \%)$ & \\
\hline Number of persons with a soft tissue lesion & $20(27.0 \%)$ & $18(24.3 \%)$ & \\
\hline Number of complete maxillary removable dental prostheses & 14 & 15 & \\
\hline Number of complete mandibular removable dental prostheses & 9 & 9 & \\
\hline Number of partial maxillary removable dental prostheses & 8 & 7 & \\
\hline Number of partial mandibular removable dental prostheses & 10 & 9 & \\
\hline Dentate persons & $n=65$ & $n=65$ & \multirow{4}{*}{$\begin{array}{c}\text { Mann-Whitney } U \text { test; } U=1526.500 \text {, } \\
P \leq 0.001\end{array}$} \\
\hline Mean number of teeth & 21.2 & 22.5 & \\
\hline Number of teeth with carious lesions & 74 & 12 & \\
\hline Number of teeth with restorations & 466 & 518 & \\
\hline Number of tooth root remnants & 24 & 5 & \multirow{3}{*}{$\begin{array}{c}\text { Mann-Whitney } U \text { test; } U=1818.000 \\
P<0.022 \\
\chi_{(2)}^{2}=18.127 ; P<0.001\end{array}$} \\
\hline Amount of biofilm and food (scores 2 and 3 ) & $39(60 \%)$ & $20(31 \%)$ & \\
\hline $\begin{array}{l}\text { Mean number of posterior functional tooth units, including } \\
\text { (implant-supported) single- and multiunit fixed dental prostheses }\end{array}$ & 3.2 & 2.8 & \\
\hline
\end{tabular}

Parkinson's disease patients had statistically significantly more teeth with carious lesions, a greater number of tooth root remnants, and a greater amount of biofilm and food when compared to the control subjects.

Only few Parkinson's disease patients and control subjects had teeth with grades II and III of tooth mobility, 11 and 6 persons, respectively. Therefore, comparisons of periodontal health between Parkinson's disease patients and control subjects were not performed.

The persons who had an edentulous maxilla/mandible, showed no statistically significant differences between Parkinson's disease patients and control subjects with regard to grades of reduction of the edentulous residual alveolar ridges.

3.4. Parkinson's Disease Patients. The distribution of the Parkinson's disease patients across duration and Hoehn and Yahr stage of the disease is presented in Table 4.

The mean duration of the disease was $9.1 \pm 6.4$ years. Reported chewing problems were statistically significantly positively related to the duration of the disease $\left(\chi_{(8)}^{2}=17.690, P=0.024\right)$. In dentate patients, the number of teeth with restorations and the number of teeth with mobility grade II or III were statistically significantly related to the duration of the disease (Kruskal-Wallis test; resp. $H_{(2)}=6.398, P=0.041$ and $\left.H_{(2)}=8.058, P=0.018\right)$.

For subsequent statistical analysis, the Hoehn and Yahr stages were dichotimized, resulting in a group of 47 patients with the mild stages 1 and 2 and a group of 27 patients with the moderate/severe stages 3, 4, and 5. The reported chewing and biting problems as well as the reported daily support for oral hygiene care by a professional or voluntary care provider were statistically significantly positively related to the Hoehn and Yahr stage of the disease (resp. $\chi_{(4)}^{2}=14.045, P=0.007$; $\left.\chi_{(4)}^{2}=10.939, P=0.027 ; \quad \chi_{(1)}^{2}=11.457, P=0.001\right)$. Furthermore, the number of teeth with carious lesions, the number of teeth with restorations, and the number of tooth
TABle 4: Distribution, including percentages, of the Parkinson's disease patients by duration (D) and Hoehn \& Yahr stage (HY) of the disease.

\begin{tabular}{lcc}
\hline D/HY & Number of patients & Percentage \\
\hline D less than 5 years & 20 & 27 \\
D between 5 and 9 years & 19 & 26 \\
D 10 years or more & 35 & 47 \\
HY1 & 16 & 22 \\
HY2 & 31 & 42 \\
HY3 & 11 & 14 \\
HY4 & 12 & 16 \\
HY5 & 4 & 6 \\
\hline
\end{tabular}

root remnants appeared statistically significantly higher in dentate patients with the moderate/severe Hoehn and Yahr stages 3-5, when compared to dentate patients with the mild Hoehn and Yahr stages 1-2 (Mann-Whitney $U$ test; resp., $U=246.500, P=0.001 ; \quad U=252.500, P=0.004$; $U=311.000, P=0.002)$.

\section{Discussion}

This is the first study which examined the most relevant aspects of the subjective as well as the objective oral health status of a large group of Parkinson's disease patients, which compared these findings with the same data of an optimally gender-, age-, social background-, and lifestyle-matched control group and which related the oral health status of the Parkinson's disease patients to the duration and severity of the disease. The findings demonstrate that more Parkinson's disease patients than control subjects reported daily oral hygiene care support by a professional or voluntary care provider, as well as chewing problems, biting problems, taste disturbance, tooth mobility, and xerostomia. Objectively, the dentate Parkinson's disease patients had a greater number of teeth with carious lesions, a greater 
number of tooth root remnants, and a greater amount of biofilm and food, when compared to the dentate control subjects. These findings represent symptoms of weakened oral health and reduced oral hygiene care, probably due to Parkinson's disease impairments. Within the group of Parkinson's disease patients, both longer duration and higher Hoehn and Yahr stage of the disease were associated with more chewing problems and, in dentate persons, with more teeth with restorations. Additionally, in dentate persons, longer duration of the disease was associated with a higher number of teeth with mobility grade II or III, whereas a higher Hoehn and Yahr stage of the disease was associated with more daily oral hygiene care support by a care provider as well as biting problems and, in dentate persons, with more teeth with carious lesions and more tooth root remnants. These findings reflect symptoms of weakening oral health, probably due to the reducing ability to manage oral hygiene care as the disease advances.

Existing data on the oral health of Parkinson's disease patients, as presented in Table 1, are extended by the results of the current study. Novel identified oral health problems include taste disturbance and more oral health problems in advanced stages of the disease. Together, these data indicate that weakening oral health and its potential negative impact on several systemic conditions are serious problems in Parkinson's disease patients, which demand more attention worldwide by the multidisciplinary Parkinson's disease medical management teams as well as standard referrals to oral health-care providers.

Chewing and biting problems, more reported by Parkinson's disease patients than control subjects, predominantly in advanced stages of the disease, may reflect (increasing) motor impairments of the orofacial system. Consequently, it is recommended to consider research of chewing and biting problems in Parkinson's disease patients with the objective to manage or reduce these problems. Other impairments of the orofacial system of Parkinson's disease patients may present as temporomandibular dysfunction. A recent study among a group of Parkinson's disease patients found temporomandibular dysfunction in about one-fifth of the patients [33]. Nevertheless, since diagnosing and classifying temporomandibular dysfunction is a rather complicated and time-consuming activity [34], we decided consciously not to include temporomandibular dysfunction as a research variable in our study. A separate and specific study on this topic is in preparation by the research groups involved in the current study.

When considered in relation to oral health, taste disturbance is certainly a novel finding in Parkinson's disease patients since none of the studies mentioned in Table 1 reported this problem. However, olfactory loss as well as smell and taste loss are well-known neurological problems in Parkinson's disease. Results of a recent (neurological) study suggest that the problems are caused by a decline of central brain networks rather than a damage of the peripheral olfactory system [35]. Previously, the olfactory deficit was demonstrated to be independent of Parkinson's disease severity and duration and preceding clinical motor symptoms by years. For this reason, taste disturbance was even suggested to be used for assessing the risk of Parkinson's disease in otherwise asymptomatic individuals [36]. From an oral health perspective, taste ability may change due to deterioration of oral health status, deficient oral hygiene, and impaired masticatory ability [37]. Additionally, saliva is of great importance since it acts as a solvent of taste substances, affects taste sensitivity, and maintains the health and function of the taste receptors. Consequently, hyposalivation results, among others, in significant altered taste sensation or taste disturbance [38]. Hyposalivation may induce oral health problems, such as tooth wear, oral soft tissue lesions, dental caries, candidiasis, and periodontal disease [39]. Nearly $65 \%$ of the Parkinson's disease patients in our study reported xerostomia (Table 2), confirming previous results demonstrating or suggesting that xerostomia and the commonly underlying hyposalivation are prevalent complications of Parkinson's disease $[28,40]$. Another saliva complication of Parkinson's disease patients is drooling. Most likely, impaired intraoral saliva clearance is the basis of its pathophysiology. However, research to explore the exact pathophysiology and to develop standard diagnostic criteria and assessment tools are needed [41]. Therefore, taste disturbance, xerostomia, hyposalivation, and drooling are topics challenging collaboration between movement disorders specialists and dentists.

Several results of the current study suggest a reduced ability to manage oral hygiene care due to Parkinson's disease impairments, which increases as the disease advances. This assumption concurs with the finding of impaired dexterity in Parkinson's disease, predominantly in advanced stages of the disease [8]. Furthermore, a recent study proved that fine motor skills in Parkinson's disease patients are impaired, predominantly in patients with mild cognitive impairment [42]. Probably, at a certain, difficult to predict stage of Parkinson's disease, patients become dependent on professional or voluntary care providers for proper daily oral hygiene care. In the current study, $15 \%$ of the Parkinson's disease patients reported as such. Unfortunately, oral hygiene care is generally not prioritized, either by the professional care providers, or by the patients themselves. Even providing a guideline to nursing home care providers and supervised implementation of this guideline did not result in a general improvement of oral hygiene of nursing home residents [43]. Subsequently, it was recommended to better integrate professional oral hygiene care into professional general health care (also in Parkinson's disease patients) in order to prevent poor oral health to become a new geriatric syndrome [44].

A retrospectively ascertained weakness of this study is the lack of data on social background and lifestyle of both the Parkinson's disease patients and the control subjects. Although the patients were requested to identify a family member or other close relative who had a similar social background and lifestyle as a control person, these variables were not actually assessed. Therefore, some selection bias cannot be ruled out.

\section{Conclusions}

The results of the current study reveal that the Parkinson's disease patients had a weakened oral health status and 
reduced oral hygiene care, when compared to an optimally gender-, age-, social background-, and lifestyle-matched control group. Additionally, both longer duration of the disease and more severe disease were associated with more oral health and oral hygiene care problems, altogether suggesting that their weakened oral health and reduced oral hygiene care are due to Parkinson's disease impairments. The authors recommend worldwide multidisciplinary Parkinson's disease medical management teams to pay more attention to their patients' oral health including standard referrals to oral health-care providers, to establish research of chewing and biting problems, taste disturbance, xerostomia, hyposalivation, and drooling in Parkinson's disease patients through collaboration of movement disorders specialists and dentists, and to integrate professional oral hygiene care into professional general health care for Parkinson's disease patients.

\section{Data Availability}

The data used to support the findings of this study are available from the corresponding author upon request.

\section{Disclosure}

The intention of this research project has been presented at the XX World Congress on Parkinson's Disease and Related Disorders in Geneva, Switzerland, 8-11 December 2013. On 4-7 December 2014, the design of this research project has been presented at the 10th International Congress on NonMotor Dysfunctions in Parkinson's Disease and Related Disorders in Nice, France. Some preliminary results of the study have been presented at the XXII World Congress on Parkinson's Disease and Related Disorders in Ho Chi Minh City, Vietnam, 12-15 November 2017.

\section{Conflicts of Interest}

The authors report no conflicts of interest.

\section{Acknowledgments}

The authors thank all research subjects involved in this case-control study and are grateful to Mrs. H. C. Bakker, who did the English editing of the final manuscript and to Dr. W. J. Klüter, Dr. J. A. H. G. Moerenburg, and Miss A. Jonker who were of great assistance in gathering the research data. This work was supported by Parkinson Vereniging (member of the European Parkinson's Disease Association), Bunnik, Netherlands, and by Foundation for Oral Health and Parkinson's Disease, Oegstgeest, Netherlands.

\section{References}

[1] K. R. Chaudhuri, D. G. Healy, and A. H. V. Schapira, "Nonmotor symptoms of Parkinson's disease: diagnosis and management," Lancet Neurology, vol. 5, no. 3, pp. 235-245, 2006.

[2] K. A. Jellinger, "Neurobiology of cognitive impairment in Parkinson's disease," Expert Review of Neurotherapeutics, vol. 12, no. 12, pp. 1451-1466, 2012.
[3] A. A. Moustafa, S. Chakravarthy, J. R. Phillips et al., "Motor symptoms in Parkinson's disease: a unified framework," Neuroscience and Biobehavioral Reviews, vol. 68, no. 9, pp. 727-740, 2016.

[4] F. Lobbezoo, "Taking up challenges at the interface of wear and tear," Journal of Dental Research, vol. 86, no. 2, pp. 101-103, 2007.

[5] F. Lobbezoo and M. Naeije, "Dental implications of some common movement disorders: a concise review," Archives of Oral Biology, vol. 52, no. 4, pp. 395-398, 2007.

[6] I. Suttrup and T. Warnecke, "Dysphagia in Parkinson's disease," Dysphagia, vol. 31, no. 1, pp. 24-32, 2016.

[7] G. R. Ribeiro, C. H. Campos, and R. C. M. Rodrigues Garcia, "Parkinson's disease impairs masticatory function," Clinical Oral Investigations, vol. 21, no. 4, pp. 1149-1156, 2017.

[8] T. Vanbellingen, B. Kersten, M. Bellion et al., "Impaired finger dexterity in Parkinson's disease is associated with praxis function," Brain and Cognition, vol. 77, no. 1, pp. 48-52, 2011.

[9] F. Müller, M. Naharro, and G. E. Carlsson, "What are the prevalence and incidence of tooth loss in the adult and elderly population in Europe?," Clinical Oral Implants Research, vol. 18, no. 3, pp. 2-14, 2007.

[10] R. L. Ettinger, "Oral health and the aging population," Journal of the American Dental Association, vol. 138, pp. 5S-6S, 2007.

[11] B. Wu, B. L. Plassman, R. J. Crout, and J. Liang, "Cognitive function and oral health among community-dwelling older adults," Journals of Gerontology Series A: Biological Sciences and Medical Sciences, vol. 63, no. 5, pp. 495-500, 2008.

[12] B. Wu, B. L. Plassman, J. Liang, and L. Wei, "Cognitive function and dental care utilization among communitydwelling older adults," American Journal of Public Health, vol. 97, no. 12, pp. 2216-2221, 2007.

[13] P. Holm-Pedersen, M. Vigild, I. Nitschke, and D. B. Berkey, "Dental care for aging populations in Denmark, Sweden, Norway, United Kingdom, and Germany," Journal of Dental Education, vol. 69, no. 9, pp. 987-997, 2005.

[14] P. Holm-Pedersen, S. L. Russell, K. Avlund, M. Viitanen, B. Winblad, and R. V. Katz, "Periodontal disease in the oldestold living in Kungsholmen, Sweden: findings from the KEOHS project," Journal of Clinical Periodontology, vol. 33, no. 6, pp. 376-384, 2006.

[15] F. A. Scannapieco and A. Cantos, "Oral inflammation and infection, and chronic medical diseases: implications for the elderly," Periodontology 2000, vol. 72, no. 1, pp. 153-175, 2000.

[16] C. D. van der Maarel-Wierink, J. N. O. Vanobbergen, E. M. Bronkhorst, J. M. G. A. Schols, and C. de Baat, "Risk factors for aspiration pneumonia in frail older people: a systematic literature review," Journal of the American Medical Directors Association, vol. 12, no. 5, pp. 344-354, 2011.

[17] C. D. van der Maarel-Wierink, J. N. O. Vanobbergen, E. M. Bronkhorst, J. M. G. A. Schols, and C. de Baat, "Metaanalysis of dysphagia and aspiration pneumonia in frail elders," Journal of Dental Research, vol. 90, no. 12, pp. 13981404, 2011.

[18] A. W. G. Walls and J. G. Steele, "The relationship between oral health and nutrition in older people," Mechanisms of Ageing and Development, vol. 125, no. 12, pp. 853-857, 2004.

[19] Y. Nakayama, M. Washio, and M. Mori, "Oral health conditions in patients with Parkinson's disease," Journal of Epidemiology, vol. 14, no. 5, pp. 143-150, 2004.

[20] J. Schwarz, E. Heimhilger, and A. Storch, "Increased periodontal pathology in Parkinson's disease," Journal of Neurology, vol. 253, no. 5, pp. 608-611, 2006. 
[21] E. R. Einarsdóttir, H. Gunnsteinsdóttir, M. H. Hallsdóttir et al., "Dental health of patients with Parkinson's disease in Iceland," Special Care in Dentistry, vol. 29, no. 3, pp. 123-127, 2009.

[22] A. Hanaoka and K. Kashihara, "Increased frequencies of caries, periodontal disease and tooth loss in patients with Parkinson's disease," Journal of Clinical Neuroscience, vol. 16, no. 10, pp. 1279-1282, 2009.

[23] M. Bakke, S. L. Larsen, C. Lautrup, and M. Karlsborg, "Orofacial function and oral health in patients with Parkinson's disease," European Journal of Oral Sciences, vol. 119, no. 1, pp. 27-32, 2011.

[24] T. Müller, R. Palluch, and J. Jackowski, "Caries and periodontal disease in patients with Parkinson's disease," Special Care in Dentistry, vol. 31, no. 5, pp. 178-181, 2011.

[25] M. Cicciù, G. Risitano, G. Lo Giudice, and E. Bramanti, "Periodontal health and caries prevalence evaluation in patients affected by Parkinson's disease," Parkinson's Disease, vol. 2012, Article ID 541908, 6 pages, 2012.

[26] A. R. Pradeep, S. P. Singh, S. S. Martande et al., "Clinical evaluation of the periodontal health condition and oral health awareness in Parkinson's disease patients," Gerodontology, vol. 32, no. 2, pp. 100-106, 2015.

[27] G. R. Ribeiro, C. H. Campos, and R. C. M. Rodrigues Garcia, "Oral health in elders with Parkinson's disease," Brazilian Dental Journal, vol. 27, no. 3, pp. 340-344, 2016.

[28] A. G. Barbe, N. Bock, S. H. M. Derman, M. Felsch, L. Timmermann, and M. J. Noack, "Self-assessment of oral health, dental health care and oral health-related quality of life among Parkinson's disease patients," Gerodontology, vol. 34, no. 1, pp. 135-143, 2017.

[29] P. M. Preshaw, "Detection and diagnosis of periodontal conditions amenable to prevention," BMC Oral Health, vol. 15, no. 1, p. S5, 2015.

[30] A. F. Käyser, "Shortened dental arches and oral function," Journal of Oral Rehabilitation, vol. 8, no. 5, pp. 457-462, 1981.

[31] W. Kalk and C. de Baat, "Some factors connected with alveolar bone resorption," Journal of Dentistry, vol. 17, no. 4, pp. 162-165, 1989.

[32] M. M. Hoehn and M. D. Yahr, "Parkinsonism: onset, progression and mortality," Neurology, vol. 17, no. 5, pp. 427-442, 1967.

[33] P. F. da Costa Silva, D. A. Biasotto-Gonzalez, L. J. Motta et al., "Impact in oral health and the prevalence of temporomandibular disorder in individuals with Parkinson's disease," Journal of Physical Therapy Science, vol. 27, no. 3, pp. 887-891, 2015.

[34] E. Schiffman, R. Ohrbach, E. Truelove et al., "Diagnostic criteria for temporomandibular disorders (DC/TMD) for clinical and research applications: recommendations of the International RDC/TMD Consortium Network and Orofacial Pain Special Interest Group," Journal of Oral \& Facial Pain and Headache, vol. 28, no. 1, pp. 6-27, 2014.

[35] E. Iannilli, L. Stephan, T. Hummel, H. Reichmann, and A. Haehner, "Olfactory impairment in Parkinson's disease is a consequence of central nervous system decline," Journal of Neurology, vol. 264, no. 6, pp. 1236-1246, 2017.

[36] A. Haehner, T. Hummel, and H. Reichmann, "A clinical approach towards smell loss in Parkinson's disease," Journal of Parkinson's Disease, vol. 4, no. 2, pp. 189-195, 2014.

[37] C. Batisse, G. Bonnet, C. Eschevins, M. Hennequin, and E. Nicolas, "The influence of oral health on patients' food perception: a systematic review," Journal of Oral Rehabilitation, vol. 44, no. 12, pp. 996-1003, 2017.
[38] H. Mese and R. Matsuo, "Salivary secretion, taste and hyposalivation," Journal of Oral Rehabilitation, vol. 34, no. 10, pp. 711-723, 2007.

[39] G.-J. van der Putten, H. S. Brand, J. M. G. A. Schols, and C. de Baat, "The diagnostic suitability of a xerostomia questionnaire and the association between xerostomia, hyposalivation and medication use in a group of nursing home residents," Clinical Oral Investigations, vol. 15, no. 2, pp. 185-192, 2011.

[40] Y. Zlotnik, Y. Balash, A. D. Korczyn, N. Giladi, and T. Gurevich, "Disorders of the oral cavity in Parkinson's disease and parkinsonian syndromes," Parkinson's Disease, vol. 2015, Article ID 379482, 6 pages, 2015.

[41] P. Srivanitchapoom, S. Pandey, and M. Hallett, "Drooling in Parkinson's disease: a review," Parkinsonism and Related Disorders, vol. 20, no. 11, pp. 1109-1118, 2014.

[42] P. Dahdal, A. Meyer, M. Chaturvedi et al., "Fine motor function skills in patients with Parkinson disease with and without mild cognitive impairment," Dementia and Geriatric Cognitive Disorders, vol. 42, no. 3-4, pp. 127-134, 2016.

[43] G.-J. van der Putten, J. Mulder, C. de Baat, L. M. J. De Visschere, J. N. O. Vanobbergen, and J. M. G. A. Schols, "Effectiveness of supervised implementation of an oral health care guideline in care homes; a single-blinded cluster randomized controlled trial," Clinical Oral Investigations, vol. 17, no. 4, pp. 1143-1153, 2013.

[44] G.-J. van der Putten, C. de Baat, L. De Visschere, and J. Schols, "Poor oral health, a potential new geriatric syndrome," Gerodontology, vol. 31, no. 1, pp. 17-24, 2014. 


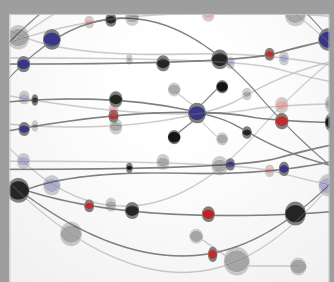

The Scientific World Journal
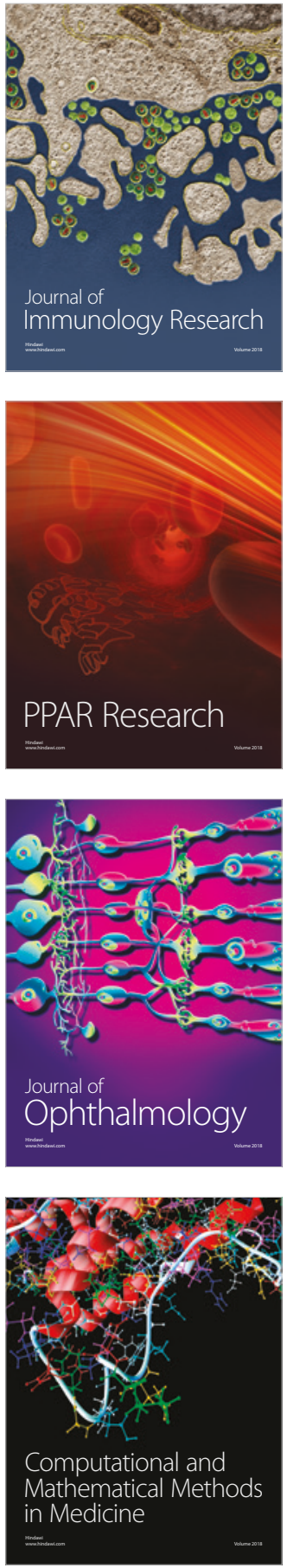

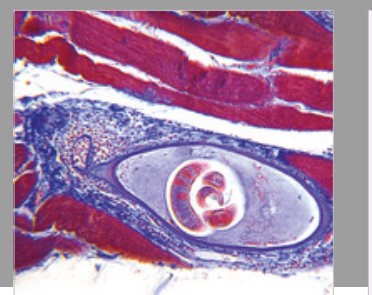

Gastroenterology Research and Practice

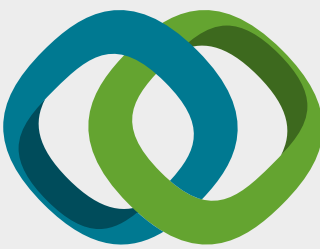

\section{Hindawi}

Submit your manuscripts at

www.hindawi.com
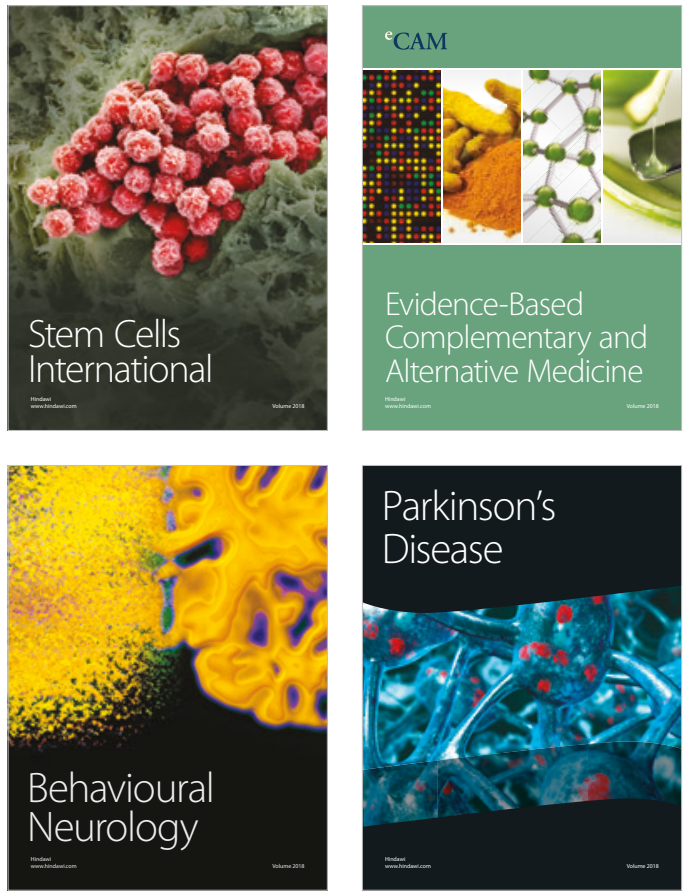

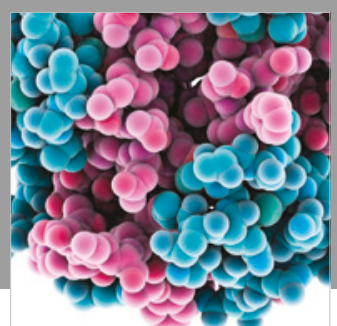

ournal of

Diabetes Research

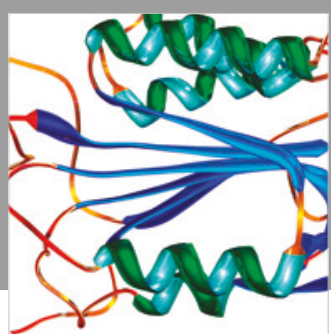

Disease Markers
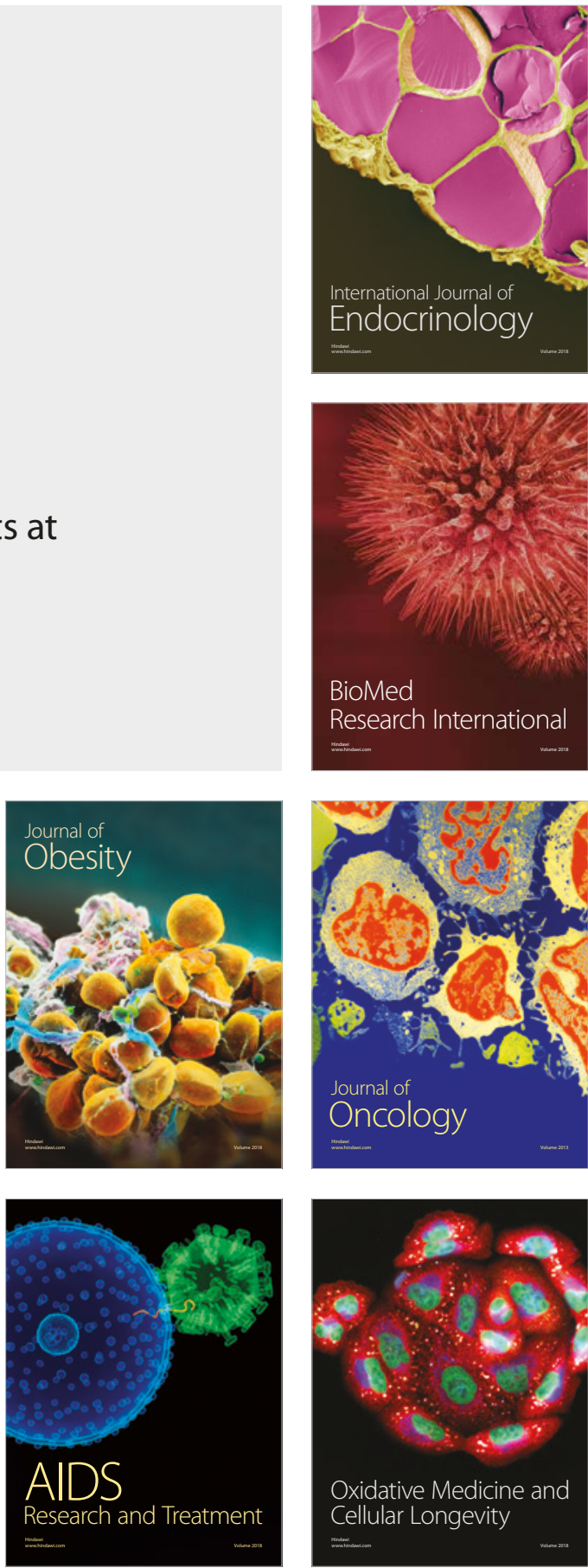